\title{
IMPACT OF SOCIO-ECONOMIC DETERMINANTS ON FOREIGN DIRECT INVESTMENT
}

\author{
ANUPAM SABHARWAL ${ }^{1}$, DR SUKHDEV SINGH ${ }^{2} \&$ DR PURAN SINGH ${ }^{3}$ \\ ${ }^{I}$ Research Scholar, CT University, Jagraon, Punjab, India \\ ${ }^{2}$ Dean Research, CT University, Ludhiana, Punjab, India \\ ${ }^{3}$ Retired Professor, S.C.D Government College, Ludhiana, Punjab, India
}

\begin{abstract}
ABSRTACT
Foreign direct investment plays a crucial role in the economic growth of developing countries. It has become more important than trade to enhance international economic transactions. The non-debt creating capital inflow of foreign investors facilitates increasing productivity, enhancing technology, strengthening infrastructure and creating employment opportunities. So every economy seeks to attract FDI through the creation of a liberal atmosphere to foreign investment and the provision of facilities and inducements to the foreign investors. Various Socio-economic determinants are influencing FDI in an economy.
\end{abstract}

KEYWORDS: Economic Growth, FDI

Received: Jun 08, 2020; Accepted: Jun 28, 2020; Published: Aug 31, 2020; Paper Id.: IJMPERDJUN2020980

\section{INTRODUCTION}

Foreign direct investment plays a crucial role in the economic growth of developing countries. It has become more important than trade to enhance international economic transactions. The non-debt creating capital inflow of foreign investors facilitates increasing productivity, enhancing technology, strengthening infrastructure and creating employment opportunities. So every economy seeks to attract FDI through the creation of a liberal atmosphere to foreign investment and the provision of facilities and inducements to the foreign investors. Various Socio-economic determinants are influencing FDI in an economy.

\section{REVIEW OF LITERATURE}

Singh Shikha (2019) ${ }^{1}$ emphasized that Indian economy since 2014 has emerged as of the one top foreign destination in the world with a significant increase in foreign direct investment. Due to proactive policy formulation by GOI especially from 2014 onwards, leads to high productivity and promoting sustainable and inclusive development. To raise foreign Capital, GOI has to look for global scale, infrastructure bottlenecks along with stringent labour laws.

Deivamani. S, et al. (2018) ${ }^{2}$ analyzed sources of Foreign Direct Investment inflows, the determinants of Foreign Direct Investment in India. As per the study, service sector, construction and development sector inflow of FDI got sustainable economic growth and development through increasing employment in India. So to make the Indian economy a developed economy, Government must proceed to elicit FDI inflows in India. 
Phiyal Kumar Ram and Sunuwar Seema (2018) $)^{3}$ analyzed the impact of FDI on economic development in developing nations like Nepal, is broadly related togrowth in employment opportunities. The analyses deduce that FDI of industry, agriculture and tourism sectors have a very significant and positive influence on GDP during the period 2007 to 2016.

Hintasova Bobenic Aneta, et al. (2018)4 identified the determinants of FDI inflows into the visegrad nations. Using the country-level data from 1989-2016 has used correlation and regression analyses identify the positive effect on FDI inflows of the level of wages and share of the educated labour force while, corporate Income Tax, expenditures on research and development andtrade openness have a negative impact on FDI inflow.

Mishra.A and Aggarwal Amba (2017) $)^{5}$ analysed the influence of FDI in five emerging countries of the world which have formed an organization called BRICS. This study tries to reveal the influence of FDI on employment and economic development in the BRICS countries. The data used for the period (2000-2015). Correlation analysis has been run to investigate the types of relationship between foreign direct investment and the unemployment growth and the economic growth in these countries. The study concludes that only Brazil and China, FDI has a positive impact on the growth rate while rest BRICS nations don't show any significant impacton growth. The influence of FDI in employment generation is not significant in all BRICS nation.

\section{DATA DESCRIPTION}

The study was carried out by secondary data. The data for FDI and socio-economic variables have been gathered from various published sources viz. RBI bulletins, World Investment Report (UNCTAD), World Bank Report, Handbook of Statistics on Indian Economy (RBI), Commerce and Industrial Development Department of India, etc. from 1991-2018. In addition to these various journals, magazines, articles and books have also been consulted.

\section{OBJECTIVES}

- To analyze the determinants of the inflow of foreign direct investment in India.

- To study the impact of socio-economic factors on FDI in India using a log-log regression model.

\section{METHODOLOGY}

The regression analysis has been carried out in two ways. Initially, the bivariate regression of all determinants is carried out in the estimable model and then multiple log-log regression model is applied,However, after a detailed analysis of the various combination of the descriptive variables, the present study includes the following macroeconomic indicators: Gross domestic product(GDP), Gross domestic savings(GDS), Per capita income(PCY), Trade Openness (TO), Financial Position (FP), an Exchange rate (ER), Foreign Exchange Reserves (FER), Gross Expenditure on Research and Development (GERD), Employment Rate(EMP), Cost of labour (C-wage), Corporate tax rate(C_TAX), Market capitalization(MARCAP), and Life expectancy(LE). These said social and economic indicators can be considered as the major determinants of FDI inflows in India. Thus, these macroeconomic indicators can be put in the following equation:

Ln FDIt $=\beta_{0}+\beta_{1} \mathrm{Ln} \mathrm{GDP}_{\mathrm{t}}+\beta_{2} \mathrm{Ln} \mathrm{GDS}_{\mathrm{t}}+\beta_{3} \mathrm{Ln} \mathrm{PCY}_{\mathrm{t}}+\beta_{4} \mathrm{Ln} \mathrm{TO}+\beta_{5} \mathrm{Ln} \mathrm{FP}_{\mathrm{t}}+\beta_{6} \mathrm{LnER}_{\mathrm{t}}+\beta_{7} \mathrm{Ln} \mathrm{EMP}_{\mathrm{t}}+\beta_{8} \mathrm{Ln}$ $\mathrm{LE}_{\mathrm{t}}+\beta_{9}$ Ln GERD $_{\mathrm{t}}++\beta_{10}$ Ln C_TAX $_{\mathrm{t}}+\beta_{11} \mathrm{LnC}_{-}-\mathrm{WAGE}_{\mathrm{t}}+\beta_{12}$ Ln MARCAP $_{\mathrm{t}}+\beta_{13} \operatorname{Ln~FER~}_{\mathrm{t}}+\mathrm{u}$

Where, 
B0is constant

$\beta 1, \beta 2, \beta 3 \ldots \ldots \ldots \beta 13$ are coefficient of FDI determinants

Ln FDI $\mathrm{t}=$ FDI inflow in Current year in India

Ln GDP = Gross Domestic Product

Ln GDS = Gross domestic savings

Ln PCY = Per capita income

Ln TO $($ Trade Openness) $=$ Ratio of export plus imports to Gross domestic product

Ln FP = Ratio of external debt to GDP

Ln ER = Exchange Rate

Ln EMP = Employment Rate

Ln LE $=$ Life Expectancy

Ln GERD = Gross expenditure on research and development

Ln C_TAX $=$ Corporate tax rate

Ln C-WAGE $=$ Rate of change in the consumer price index for industrial workers

Ln MARCAP $=$ Market capitalization on BSE

Ln FER =Foreign Exchange Reserves

$\mathrm{u}=$ Error Term

\section{RESULTS AND DISCUSSIONS}

To study the significance of each determinant in the absence of others a bivariate log-log regression model has used for each determinant that is discussed above, with the FDI inflow in India.It depicts the nature and extent of association that exists between two determinants when other determinants are remaining constant.Both FDI and factors affecting FDI are expressed in logarithmic form. The model takes the following form:

In $\mathrm{FDI}_{\mathrm{t}}=\beta_{0}+\beta_{1} \operatorname{Ln}\left(\mathrm{X}_{\mathrm{n}}\right)+\mathrm{u}$

Where,

$\mathrm{FDI}_{\mathrm{t}}=$ Current year inflow of FDI

$\beta_{0}=$ Constant

$\beta_{1}=$ Coefficient

$\mathrm{X}_{\mathrm{n}}=$ Determinant

$\mathrm{u}=$ Error term

$\mathrm{n}=1,2,3$. \& 14 
The outcomes of bivariate log-log regression models are shown in the following table.

Table 1: Dependent Variable: Ln FDI Log-Log Model

\begin{tabular}{|l|l|c|c|c|c|c|}
\hline S. No. & $\begin{array}{c}\text { Determinants of } \\
\text { FDI }\end{array}$ & Constant & Coefficient & $\begin{array}{c}\text { SE of } \\
\text { Coefficient }\end{array}$ & $\begin{array}{c}\mathbf{R}^{2} \\
\text { (R square })\end{array}$ & p-value \\
\hline 1. & Ln GDP & -19.84 & 2.12 & .145 & 0.891 & .000 \\
\hline 2. & Ln GDS & -13.57 & 1.83 & .121 & 0.898 & .000 \\
\hline 3. & Ln PCY & -7.638 & 2.52 & .185 & 0.878 & .000 \\
\hline 4. & Ln TO & -5.743 & 4.21 & .336 & 0.858 & .000 \\
\hline 5. & Ln FER & -6.494 & 1.35 & .068 & .937 & .000 \\
\hline 6. & Ln ER & -12.061 & 5.57 & .589 & .775 & .000 \\
\hline 7. & Ln GERD & -8.583 & 1.73 & .233 & .697 & .000 \\
\hline 8. & Ln EMP & 131.08 & -30.55 & 3.625 & .732 & .000 \\
\hline 9. & Ln FP & 30.001 & -6.77 & 1.359 & .489 & .000 \\
\hline 10. & Ln C-TAX & -1.265 & 2.93 & 3.842 & .022 & .451 \\
\hline 11. & Ln C_WAGE & 16.407 & -1.29 & .738 & .109 & .087 \\
\hline 12. & Ln LE & -120.72 & 31.21 & 1.805 & .920 & .000 \\
\hline 13. & Ln MARCAP & -2.58 & 1.17 & .089 & .871 & .000 \\
\hline
\end{tabular}

- Above table showsthat the first determinant i.e. GDP in India is the mainimportantfactor in attracting FDI inflows. FDI's elasticity with respect to change in gross domestic product is $2.12 \%$ in the same direction.

- Gross domestic savings that lead to capital formation in the economy is an important factor to attract FDI in an economy. The estimated coefficient reveals that $1 \%$ changes in gross domestic saving would lead to a $1.83 \%$ change in the inflow of FDI.

- Rising per capita income is also a significant determinant of FDI, as increase income leads to more demand and growth of the market. Hundredth change in per capita income is resulted to cause about $2.52 \%$ change in FDI inflow in India.

- Trade openness of the economy which is represented by trade to GDP ratio was also found to be an important determinantat $1 \%$ level with a positive sign. $1 \%$ change in trade openness is resulted in $4.21 \%$ variation in FDI inflow in India, in the same direction.

- Foreign Exchange reserves withthe highest $\mathrm{R}^{2}$ that is $0.93 \%$ as compared to that of other determinants possess the positive sign. $1 \%$ growth in foreign exchange reserves leads to a $1.35 \%$ increase in FDI.

- Since 1991 Indian economy has undergone major changes and that changes are revealed in the Indian Industry too. The rate of change in FDI inflow due to $1 \%$ change in the exchange rate is calculated at $5.57 \%$.

- The Gross expenditure on research and development representing the expenditure on human capital formation reveals a negative sign and also found stability significant. Due to one percent change in FDI inflow, the cost of GERD change is computed at $1.73 \%$.

- Employment to population ratio one percent change would lead to a $30.5 \%$ change in FDI in the opposite direction.

- The estimated coefficient that $1 \%$ changes in financial position would lead to a change in FDI inflow by about $6.77 \%$ in the opposite direction. 
- The rate of corporate tax collected has a positive sign and also found significant.

- The cost of labour proxies by the rate of change in the CPI for industrial workers has a negative and significant relationship with FDI inflows in India. Computed co-efficient shows that $1 \%$ change in the movements of wage leads to by $1.29 \%$ change the FDI inflow in an opposite direction.

- High life expectancy shows better human resources of an economy. $1 \%$ increase in life expectancy is estimated to cause a 31.2 percent increase in FDI.

- The market capitalization of Bombay stock exchange, a proxy for capital market strength, is positively associated with FDI inflow in India and reveals significant relation at the five percent level.

\section{Multiple Regression Analysis}

\begin{tabular}{|c|c|c|c|}
\hline \multicolumn{4}{|c|}{$\begin{array}{l}\text { In this paper,a multiple log-log regression mode } \\
\text { Dependent Variable: Ln FDI } \\
\text { b. Predictors in the Model: (Constant), Ln FER }\end{array}$} \\
\hline \multicolumn{2}{|l|}{ R-squared } & 0.979803 & \\
\hline \multicolumn{2}{|l|}{ F-statistic } & 44.78089 & \\
\hline \multicolumn{2}{|l|}{ Prob (F-statistic) } & 0.000000 & \\
\hline Variable & Coefficient & Standard error & t-statistics \\
\hline $\mathrm{C}$ & 553.5050 & 186.0551 & 2.974952 \\
\hline LN_C_TAX & 2.445441 & 3.225868 & 0.758072 \\
\hline LN_C_WAGE & 0.183963 & 0.479677 & 0.383514 \\
\hline LN_EMP & -21.69753 & 17.90790 & -1.211617 \\
\hline LN_FP & -2.781601 & 1.161064 & -2.395735 \\
\hline LN_GERD & 0.013171 & 0.248389 & 0.053024 \\
\hline LN_TO & 2.883642 & 1.359145 & 2.121659 \\
\hline LNER & 9.221631 & 2.992296 & 3.081792 \\
\hline LNFER & 1.833699 & 0.876801 & 2.091351 \\
\hline LNGDP & -41.82276 & 23.66442 & -1.767326 \\
\hline LNGDS & 1.001306 & 1.995617 & 0.501752 \\
\hline LNLE & -66.84209 & 66.03387 & -1.012240 \\
\hline LNMARCAP & -0.753976 & 0.431742 & -1.746356 \\
\hline LNPCY & 48.00565 & 23.62315 & 2.032144 \\
\hline
\end{tabular}

R square of log-log multiple regression is 0.9798 and Trade openness (TO), foreign exchange reserves (FER), financial position (FP) and exchange rate(ER) show significant relation with FDI, while other variables are showing insignificant relation.

\section{CONCLUSIONS}

The above analysis reveals that Trade openness, foreign exchange Reserves, FIN. Position and Exchange rate are the major determinants of FDI inflows to the country. These macroeconomic variables have anintensestimulus on the inflows of FDI in India. The results of the log-log multiple regression model reveal that Trade openness, foreign exchange Reserves, and exchange rate variables display a positive relationship with FDI while FIN. Position variables exhibit a negative relationship with FDI inflows. Thus, it is concluded that the above analysis is successful in identifying those variables which are important in attracting FDI inflows in India. 


\section{REFERENCES}

1. Singh Shikha. (2019). “Foreign Direct Investment (FDI) Inflows in India” Journal of General Management Studies, vol.6, Issue1, January 2019, pp.47-53.

2. S Deivamani, Meena Devi Gopi, and G Poorna Abirami (2018) “International Journal of Academic Research and Development” ISSN: 2455-4197 Impact Factor: RJIF 5.22 www.academicsjournal.com Volume 3; Issue 1; January 2018; Page No. 1149-1153.

3. Phuyal, Ram Kumar and Sunuwar, Seema (2018) “Journal of Business and Social Sciences Research (JBSSR)”, Vol. 3, No. 1, pp. 1-14.

4. Hintošová, Bobenič Aneta, et al.(2018) "Determinants of foreign direct investment inflows: A case of the Visegrad countries." Journal of International Studies, 11(2), 222-235.

5. Mishra A. \& Agarwal A. "Analysis of Impact of FDI on Economic Growth and Employment A Study of (BRICS) Nations".International Journal of Management Research and Review (IJMRR) Volume 7/Issue 6/Article No-10/706-714) June 2017.ISSN- 2249-7196.

6. $\quad$ http://articles.economictimes.indiatimes.com

7. http://dipp.nic.in

8. http://indiainbusiness.nic

9. http://unctad.org

10. http://www.business-standard.com

11. http://www.investindia.gov.in

12. http://www.mea.gov.in

13. http://www.worldbank.org

14. https://dbie.rbi.org.in/DBIE/dbie.rbi?site=statistics

15. Government of India, Annual Report. (1992-93), (1993-94), (2004-2005),( 2005-2006), (2007-2008), (2009-2010), (20132014), (2014-2018). Ministry ofFinance.

16. UNCTAD, WIR. (2003, 2009, 1995, 1998, 1999, 2015, 2018). World Investment Report 